Biophys., 13: 103-114. - Jost A., Vigier B., Prepin J. \& Prechellet J.-P., 1973b: Studies on sex differentiation in mammals. Rec. Prog. Horm. Res., 29: 1-41. Kałuziński J., 1982: Dynamics and structure of field roe deer population. Acta theriol., 27: 385-408. - Lillie F. R., 1916: Theory of the Freemartin. Science, 43: 611-613. - Marcum J. B., Lasley J. F. \& Day B. N., 1972: Variability of sex chromosome chimerism in cattle from heterosexual multiple births. Cytogenetics, 11: 388-399. - Ohno S., 1979: Major sex-determining genes. Springer Verlag, Berlin, Heidelberg, New York. - Strandgaard H., 1972a: The roe deer (Capreolus capreolus) population of Kalø and the factors regulating its size. Danish Rev. Game Biol., 7: 1-204. - Strandgaard H., 1972b: An investigation of corpora lutea, embryonic development, and time of roe deer (Capreolus capreolus) in Denmark. Danish Rev. Game Biol., 6: 1-22. - Sokolov V. E., Orlov V. N., Chudinovskaja G. A., \& Danilkin A. A., 1978: Differences in chromosomes between two subspecies Capreolus capreolus L. and C. c. pygargus Pall. Zool. Ž., 57: 1109-1112. - Sysa P.S., Sławomirski J. \& Kuńska A., 1980: Cytogenetyczne badania nad frymartynizmem u bydła. Medycyna Wet. 36: 225-228. - Vigier B., Prepin J. \& Jost A., 1972: Absence de correlation entre le chimerisme $X X / X Y$ dans le foie et les premiers signes du freemartinisme chez le foetus de Veau. Cytogenetics, 11: 81-101. Volobujev V. T.: The B-chromosome system of mammals. Genetica, 52/53: 33-337. - Wurster D. \& Benirschke K., 1967: The chromosomes of twenty-three species of the Cervoidea and Bovoidea. Mammalian Chromosomes Newsletter, 8: 226. Zernahle K., 1980: Zytogenetische Untersuchungen am Europäischen Rehwild (Capreolus c. capreolus L., 1758), Sibirschen Rehwild (Capreolus c. pygargus, Pallas 1771) und deren Bastarden. Beiträge zur Jagd- und Wildforschung, 11: 304-309.

Accepted, November 20, 1983.

\title{
Food of the Long Eared Hedgehog in Ravines Near Agra
}

\author{
POKARM JEZA USZATEGO W OKOLICACH AGRY
}

\section{U. K. MAHESHWARI ${ }^{1}$}

\begin{abstract}
Maheshwari U. K., 1983: Food of the long eared hedgehog in ravines: near Agra. Acta theriol., 29, 10: 137-140 [With 2 Tables]

Annual and seasonal food composition of 165 long eared hedgehog Hemiechinus auritus collaris (Gray, 1830) studied from their stomach contents revealed that the main diet composed of insects $(47.4 \%$ by number method and $39.74 \%$ by weight method). Beetles constituted more than $75 \%$ of the insect food. Oligochaetes, amphibians, reptiles and mammals also occurred in low proportion $(7-10 \%)$. It appears that the food of the hedgehogs is related to the availability of the prey.
\end{abstract}

[Department of Zoology, Agra College, Agra 282 002, India].

\section{INTRODUCTION}

The long eared hedgehog Hemiechinus auritus collaris (Gray, 1830) is fairly common in chalesar ravines near Agra, India. It has been

1 Present address: 16/24, Rawat Para, Agra -282003 , India. 
observed in the Thar desert that the hedgehogs feed mostly on the coleopteran insects, egg shells, amphibians etc. (Krishna \& Prakash, 1960). However, the available information on the food and feeding habits of the insectivore $H$. a. collaris in nature is scanty and therefore a detailed study of its composition of food in nature was carried out during 1975 and 1976. The results of the study are presented in this communication.

\section{STUDY AREA}

The study was conducted in chalesar ravines $\left(27^{\circ} 10^{\prime} \mathrm{N}\right.$ and $\left.78^{\circ} 02^{\prime} \mathrm{E}\right), 14 \mathrm{~km}$ east of Agra, on the western bank of river Jamuna. In general the topography is very undulating, the slopes vary from steep to very steep. It harbours a large variety of trees: Acacia nilotica, Dalbergia sisso, Prosopis spp. and Dendrocalamus stricusus. Among other plants Caparis decidua, Tamarix spp., Zyzyphus nummularia, Calotropis spp. and Tephrosia purpurea are common.

\section{METHODS}

The hedgehogs, Hemiechinus auritus collaris were collected in all the seasons during 1976 and 1977. They were sexed, weighed and dissected to remove the alimentary canal. The contents of the stomachs were collected in petridishes and subjected to the analysis by the following methods. They were also identifien to various zoological groups.

Number method. In this method, the number of individual food organisms was recorded and expressed as percentage of the total number of food items in the stomach (Hynes, 1950).

Weight method. The stomach contents were oven dried at $30-40^{\circ} \mathrm{C}$ and weighed on semi-micro Mettler balance. All the food items of various seasons were also weighed (Murton et al., 1964).

\section{RESULTS AND DISCUSSION}

The analysis of the food of the hedgehogs on an annual basis (Table 1) indicates that its main food is composed of insects $(47.45 \%$ number method and $39.74 \%$ weight method; beetles constituting about $75 \%$ of the total insects consumed). Oligochaetes, crustaceans, amphibians, reptiles and mammals occurred in the stomach 3 of the hedgehogs almost in equal proportion $(7-10 \%)$. Bird feathers and egg shells were also found in low quantity.

Analysis of stomach contents on a seasonal basis (Table 2) indicate that the variation in the food item between seasons is not significant. Surprisingly the intake of oligochaetes, crustanceans, and amphibians increased during this season as compared to winter and summer. The occurrence of reptiles in stomach contents was found to be maximum during summer $(15 \%)$. Mammals fell prey in maximum proportion $(26.9 \%)$ during winter months. Likewise arachnids were consumed in large quantity during summer (Table 2).

From the above it appears that the food of the hedgehog, H. a. collaris is related to the availability of prey and that it is not a selective feeder, as also observed by Krishna \& Prakash (1960). The earthworms move towards the soil surface during monsoon and they are probably available 
to them in abundance. Likewise, crustaceans and amphibians, mostly younger animal, are available to hedgehogs relatively in large number during monsoon as most of them breed during this season and thus fall easy prey to the hedgehogs.

The preference of hedgehogs for insects and especially beetles could be due to the odour emmited from their body (Brockie, 1959; Dimelow, 1963) which probably makes it easy for the hedgehog to trap them.

Table 1

Per cent occurrence of various food items in the stomach of 165 hedgehogs collected from nature during two years 19 stomach were found to be empty.

\begin{tabular}{|c|c|c|c|}
\hline \multirow{2}{*}{ Food items } & \multirow{2}{*}{$\begin{array}{c}\text { Number of } \\
\text { stomachs in } \\
\text { which occturred }\end{array}$} & \multicolumn{2}{|c|}{ Percent occurrence } \\
\hline & & Number method & Weight method \\
\hline \multicolumn{4}{|l|}{ Annelida } \\
\hline Oligochaeta & 67 & 8.85 & 10.22 \\
\hline Arthropoda & & & \\
\hline Coleoptera & 114 & 28.24 & 30.83 \\
\hline Diptera & 70 & 7.63 & 3.28 \\
\hline Lepidoptera & 47 & 3.79 & 2.37 \\
\hline Dermaptera & 18 & 1.79 & 1.17 \\
\hline Hymenoptera & 49 & 6.00 & 2.09 \\
\hline Arachnida & 39 & 4.42 & 2.30 \\
\hline Chelopoda & 36 & 5.26 & 10.40 \\
\hline Diplopoda & 16 & 2.31 & 1.52 \\
\hline Isopoda & 10 & 1.73 & 0.20 \\
\hline Amphibia & 66 & 8.42 & 13.41 \\
\hline Reptilia & 78 & 8.16 & 7.29 \\
\hline Aves & 27 & 2.79 & 0.52 \\
\hline Mammalia & 45 & 7.42 & 10.34 \\
\hline
\end{tabular}

Table 2

Percent occurrence of various foods of the hedgehog during the three seasons (weight method).

\begin{tabular}{lccr}
\hline \multirow{2}{*}{ Food items } & \multicolumn{3}{c}{ Per cent occurrence $(\%$ weight $)$} \\
\cline { 2 - 4 } & Winter & Summer & Monsoon \\
\hline Annelids & 3.89 & 8.73 & 14.38 \\
Insects & 43.86 & 46.73 & 34.66 \\
Arachnids & 2.77 & 6.53 & 0.14 \\
Crustaceans & 4.53 & 4.17 & 19.91 \\
Amphibians & 5.37 & 9.37 & 19.66 \\
Reptiles & 9.70 & 15.00 & 3.06 \\
Aves & 1.16 & 0.80 & 0.04 \\
Mammals & 26.94 & 4.66 & 3.69 \\
Unidentified material & 2.68 & 4.66 & 4.38 \\
\hline
\end{tabular}

Yalden (1976) also suggested that hedgehogs searched carabid beetles due to the presence of chemicals and their odour in the body.

No plant material was found from the stomach contents of hedgehogs, confirming Prakash's (1956) observations. However, Kalabukhov (1928) suggested that vegetable matter may be eaten occasionally to quench 
thirst. This explanation, however, does not appear to be feasible since the water contents in insect body is very high (Robinson, 1928). However, Yalden (1976) and Campbell (1973) also found substantial quantity of plant in stomachs of the European hedgehogs, Erinacenus europaeus. It is interesting that the food of the two hedgehogs Hemiechinus and Erinaceus residing different habitats differ pertaining to vegetable food, similar variation in the natural food of the insectivorous shrew, Suncus murinus sindensis, has been observed. In Rajasthan, it chiefly feeds on vegetation $(90.7 \%$ ) on an annual basis (Advani \& Rana, 1981) whereas in Pakistan it is reported to prefer insects (Roberts, 1977).

\section{REFERENCES}

Advani R. \& Rana B. D., 1981: Food of the house shrew, Suncus murinus sindensis in the Indian desert. Acta theriol., 26: 133-134. - Brockie R. W., 1959: Observation of the food of hedgehog (Erinaceus europaeus L.) in New Zealand. New Zealand J. Sci., 2: 121-136. - Campbell P. A., 1973: Feeding behaviour of $\mathrm{Ph}$. D. thesis, University of Canterbury, Lincoln College. p. 1-276. - Dimelow J. E., the European hedgehog (Erinaceus europeaus L.) in a New Zealand pasteur. 1963: Observations on the feeding of hedgehog (Erinaceus europaeus L.). Proc. zool. Soc., Lond., 141: 291-309. - Hynes H. B. N., 1950: The food of the fresh water labacks with a view of the methods used in the studies of the food of the fishes. J. Anim. Ecol., 19: 36-58. - Kalabukhov N. I., 1928: Über die Nahrung des Igels in Nordkaukasus, and der Ukraine. Mitt. Nordkauk. pfi. Shutz Stat. Rostow Don, 4: 62-68. - Krishna D. \& Prakash I., 1960: Hedgehogs of the desert of Rajasthan. Part III. Food in nature. Proc. Raj. Acad. Sci., 7: 60-62. Murton R. K., Westwood M. J. \& Isaacson A. J., 1964: Feeding habits of the wood pigeon, Columbia palumbus, Stockdove, Columbia oenas and Turtle dove, Streptopelia turtur. Ibis, 106: 174-188. - Prakash I., 1956: Studies on the ecology of desert hedgehogs. Proc. Raj. Acad. Sci., 6: 24-38. Roberts T. J., 1977: The mammals of Pakistan. Ernest Benn Ltd., XXVI+1-361. - Robinson W., 1928: Water conservation in insects. J. Econ. Entomology, 21: 897-902. - Yalden D. W., 1976: The food of the hedgehog in England. Acta theriol, 1: 401-424.

Accepted, November 16, 1983. 